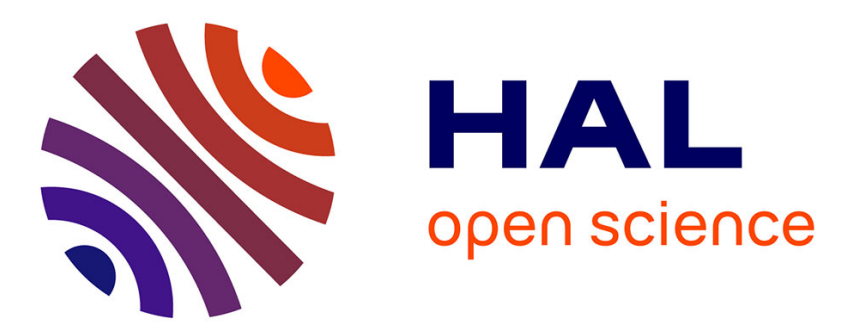

\title{
Effect of organic manure and the endogeic earthworm Pontoscolex corethrurus (Oligochaeta: Glossoscolecidae) on soil fertility and bean production
}

Stéphanie Topoliantz, Jean-François Ponge, Dominique Arrouays, Sylvain Ballof, Patrick Lavelle

\section{To cite this version:}

Stéphanie Topoliantz, Jean-François Ponge, Dominique Arrouays, Sylvain Ballof, Patrick Lavelle. Effect of organic manure and the endogeic earthworm Pontoscolex corethrurus (Oligochaeta: Glossoscolecidae) on soil fertility and bean production. Biology and Fertility of Soils, 2002, 36 (4), pp.313-319. 10.1007/s00374-002-0535-8 . hal-00499529

\section{HAL Id: hal-00499529 \\ https://hal.science/hal-00499529}

Submitted on 20 Aug 2010

HAL is a multi-disciplinary open access archive for the deposit and dissemination of scientific research documents, whether they are published or not. The documents may come from teaching and research institutions in France or abroad, or from public or private research centers.
L'archive ouverte pluridisciplinaire HAL, est destinée au dépôt et à la diffusion de documents scientifiques de niveau recherche, publiés ou non, émanant des établissements d'enseignement et de recherche français ou étrangers, des laboratoires publics ou privés. 
Effect of organic manure and the endogeic earthworm Pontoscolex corethrurus (Oligochaeta: Glossoscolecidae) on soil fertility and bean production

Stéphanie Topoliantz · Jean-François Ponge $\cdot$ Dominique Arrouays $\cdot$ Sylvain Ballof $\cdot$ Patrick Lavelle

S. Topoliantz (®) J J.-F. Ponge

Museum National d'Histoire Naturelle, Laboratoire d'Ecologie Générale, 4 Avenue du Petit-Château, 91800 Brunoy, France

e-mail: Stephanie.Topoliantz@wanadoo.fr

Tel.: +33-1-60479213, Fax: +33-1-60465009

D. Arrouays

Institut National de la Recherche Agronomique, Unité Infosol, Avenue de la Pomme de Pin, BP 20619, Ardon, 45166 Olivet Cedex, France

S. Ballof

Office National des Forêts, BP 9, 97370 Maripasoula, French Guyana

P. Lavelle

Laboratoire d'Ecologie des Sols Tropicaux, Centre IRD Ille-de France, 32 Rue Henri Varagnat, 93143 Bondy Cedex, France

\footnotetext{
Abstract A biofertilisation assay was conducted in Maripasoula (French Guiana), testing the effects of three different organic amendments (manioc peels, sawdust and wood charcoal) and the inoculation of the endogeic earthworm Pontoscolex corethrurus on pod production of Vigna unguiculata sesquipedalis and on soil chemical
} 
properties $(\mathrm{pH}, \mathrm{C}, \mathrm{N}$, total and exchangeable $\mathrm{P}$ and $\mathrm{K})$. Pod production was highest with manioc peels as available $\mathrm{P}$ increased in the soil. Wood charcoal also had a beneficial effect on pod production as it decreased acidity and increased the $\mathrm{C}: \mathrm{N}$ ratio in the soil. In sawdust-amended soil, pod production did not differ from that in unamended soil. Inoculation of earthworms at a density of 80 sub-adults m-2 did not significantly affect either pod production or soil nutrient content directly, although it increased the positive effect of manioc peels on pod production. Soil nutrient content, pod production and earthworm density at the end of the experiment were negatively correlated with soil moisture and positively with each other. Despite the strong effect of moisture, this assay demonstrated an interaction between the earthworm $P$. corethrurus and the legume $V$. unguiculata sesquipedalis mediated by soil nutrient content and organic matter inputs. We conclude that manioc peels improved soil $\mathrm{P}$ availability and were an interesting amendment for legume crops. We discuss also the effect of earthworm inoculation.

Keywords Pontoscolex corethrurus · Vigna unguiculata sesquipedalis · Earthworm density · Soil nutrient content $\cdot$ Manioc peels

\section{Introduction}

In tropical areas, the fertility of cultivated soil is maintained under traditional shifting cultivation but under demographic pressure and the accompanying more intensive land use, the duration of fallow diminishes, leading to a decrease in soil fertility and plant production (Clarke 1976). Many research studies have been conducted in agricultural fields to improve soil fertility and plant growth while limiting the use of mineral fertilisers (Palm et al. 2001; Tiessen et al. 2001). In several tropical countries, new techniques of "biofertilisation", adding organic manures and earthworms to soil, have been tested (Senapati et al. 1999). These methods are based on the degradation and humification of predominantly low quality organic matter by earthworm and microbial activities which improves soil structure and nutrient content (Lavelle et al. 2001). In India, biofertilisation techniques using tea pruning debris as the organic input increased tea production by more than $200 \%$ when compared with unfertilised controls, and by $80 \%$ when compared to mixed organic and inorganic fertilisation (Senapati et al. 1999). Sawdust with earthworm inoculation has been used in Peru for tomato crops, doubling production when compared with non-amended soil and reaching the same level as inorganic fertilisers (Senapati et al. 1999). 
In the present study, a biofertilisation assay was conducted at Maripasoula (French Guiana), where vegetable production on permanently cultivated soils is low. This field experiment was based on the principles of biofertilisation techniques which improve fertility and soil structure through the combined effect of earthworm activity and manuring while avoiding the use of inorganic fertilisers. Particular attention was given to making the assay easily practicable by local farmers. In this perspective, we tested different organic residues which are currently produced in this region such as manioc peels, wood charcoal and sawdust, and we measured their manuring effects on a legume consumed locally. The earthworm species used for faunal inoculation was Pontoscolex corethrurus (Oligochaeta, Glossoscolecidae), currently found at Maripasoula. This species, now dispersed by man worldwide, is probably indigenous to the Guyana plateau in South America (Righi 1984). It exhibits a high capacity for adaptation to soil disturbance and is abundant in open fields of tropical regions (Lavelle et al. 1987). Several studies have shown high concentrations of mineral $\mathrm{P}$ and $\mathrm{N}$ in casts and resulting effects on plant growth (Barois et al. 1987; Lopez-Hernandez et al. 1993). P. corethrurus is often used for biofertilisation due to these qualities (Senapati et al. 1999). Our bioassay, which aimed to improve soil fertility for legume production without using inorganic fertilisers, provides original results through the use of charcoal and manioc peels as new amendments in field experiments.

\section{Materials and methods}

Bioassay design

The bioassay was conducted at Maripasoula $\left(3^{\circ} 38.663^{\prime} \mathrm{N} ; 054^{\circ} 02.433^{\prime} \mathrm{W}\right)$, in a field that had not been cultivated for 4 years and was currently covered by herbaceous vegetation. In December 2000, during the dry season, vegetation was cut and soil was harrowed by hoe to a $20-\mathrm{cm}$ depth. The chemical composition of the soil is detailed in Table 1 . The natural population of $P$. corethrurus in the studied field, including all age classes, was estimated under herbaceous cover at 37.3 individuals $\mathrm{m}-2 \pm 7.3$ (mean $\pm \mathrm{SE}$ ) in the upper first $30 \mathrm{~cm}$, using the TSBF method (Anderson and Ingram 1993).

The experiment consisted of testing the effects of different amendments, earthworm inoculation and the presence of a legume. Three amendments were used, peels of bitter manioc (Manihot esculenta Cranz; M), wood charcoal (Ch) and sawdust ( $\mathrm{Sw}$ ), which were compared to unamended soil (NoA). The chemical composition of amendments is given in Table 2. Sixteen treatments were tested: $\mathrm{M}, \mathrm{Ch}, \mathrm{Sw}$ or NoA, each crossed with 
inoculation of earthworms $(\mathrm{Ew})$ or not $(\mathrm{NoEw})$ and presence of legumes $(\mathrm{L})$ or not $(\mathrm{NoL})$. The 16 treatments were randomly disposed in 3 replicate blocks each containing 16 plots $1 \mathrm{~m}$ distant from each other. Each $0.25-\mathrm{m}^{2}$ plot was delineated by wooden frames $50 \mathrm{~cm}$ in length, $50 \mathrm{~cm}$ in width and $16 \mathrm{~cm}$ in height. The total 48 plots were not closed at depth. This allowed the natural movement of earthworms between plots (inoculated and natural population), in order to see a possible attractive or repulsive effect of amendments. Amendments (M, Ch and Sw) were mixed with the upper $15 \mathrm{~cm}$ of the soil in a $1: 3 \mathrm{v}: \mathrm{v}$ ratio. In half of the plots, the earthworm $P$. corethrurus, collected in different open fields of the village during the dry season, was inoculated at a rate of 80 subadults $\mathrm{m}^{-2}$, i.e. $30-40 \mathrm{~g}$ fresh weight $\mathrm{m}^{-2}$. In 24 plots, nine yard-long bean (Vigna unguiculata sesquipedalis) seeds were directly sown into the soil and distributed in three batches. Yard-long bean pods were continuously harvested for 2 months (February 2001-March 2001) and their fresh weight was measured. At the final harvest, 4 months after the start of the experiment, earthworms were sampled in all plots to $15 \mathrm{~cm}$ depth and $P$. corethrurus individuals were counted. We could not distinguish individuals of the natural population from inoculated ones. With the soil being wet, soil surface moistening state was noticed with a semi-quantitative index based on visual observation as follows:

1. No moistening features

2. Moist but without free water on the ground

3. Less than one quarter of the quadrat water-logged

4. Quarter of the quadrat water-logged

5. At least half of the quadrat water-logged

6. Totally water-logged

Soil was sampled in each plot for analyses.

Soil chemical analyses

Soil samples were air-dried and sieved $(<2 \mathrm{~mm})$ prior to chemical analysis. Soil $\mathrm{pH}$ was determined in a 1:2.5 (w:w) soil-water suspension (NF ISO 10390; AFNOR 1996). Total C and total N were measured after dry combustion (NF ISO 10694 and 13878; AFNOR 1996). Available P ( $\left.\mathrm{P}_{\mathrm{av}}\right)$ was determined by the Olsen method. 
Exchangeable $\mathrm{K}$ was measured by two methods, after hexamine cobalt extraction $\left(\mathrm{K}_{\mathrm{co}}\right)$ at soil $\mathrm{pH}$ and after ammonium acetate extraction $\left(\mathrm{K}_{\mathrm{ac}}\right)$ at $\mathrm{pH}$ 7. Total $\mathrm{P}\left(\mathrm{P}_{\mathrm{tot}}\right)$ and total $\mathrm{K}\left(\mathrm{K}_{\mathrm{tot}}\right)$ were measured after hydrofluoric acid extraction.

\section{Statistical analyses}

Data analysed were (1) the number of mature yard-long bean shoots, (2) the mean fresh weight of pods, (3) the bean plant survival between start and final harvest, (4) the density of P. corethrurus after 4 months, and (5) soil acidity and nutrient content (total $\mathrm{C}$, total $\mathrm{N}$, available and total $\mathrm{P}$, exchangeable and total $\mathrm{K}$, their ratio and difference). Statistical analyses were conducted with the Sigmastat (version 2.03) program. The effects of amendment and earthworm inoculation on plant data were analysed by a two-way ANOVA on the 24 plots sowed with bean seeds. The effects of amendment and earthworm inoculation on earthworm density and soil chemical properties were tested by a two-way ANOVA, isolating plots with bean plants from those without because the number of mature shoots differed among sown plots. The relation between the presence of legumes and earthworm density on the one hand and soil chemical properties on the other was tested in the 48 plots by Spearman rank correlation $\left(r_{\mathrm{s}}\right)$. When necessary data were log-transformed before ANOVA ( $\mathrm{K}_{\mathrm{tot}}$ in NoL plots). Differences between means of $\mathrm{C}: \mathrm{N}, \mathrm{K}_{\mathrm{tot}}-\mathrm{K}_{\mathrm{ac}}, \mathrm{K}_{\mathrm{tot}}-\mathrm{K}_{\mathrm{co}}$, that did not follow a normal distribution after logtransformation, were analysed by a Kruskall-Wallis rank test (Sokal and Rohlf 1995). Means were compared with a Tukey a posteriori test. Correlations between quantitative and semi-quantitative data were tested by Spearman rank correlation. Comparisons between two groups were done by a Mann-Whitney rank test.

\section{Results}

Effects of amendment and earthworm inoculation on biological parameters

From nine seeds sown per plot, we found three to eight mature bean shoots $(5.5 \pm 1.1$; mean \pm SE). Effects of amendments and earthworm inoculation on the number of mature shoots were not significant (Table 3). Neither bean production nor plant survival were significantly correlated with the number of shoots per plot $\left(r_{\mathrm{s}}=0.035\right.$;

$P=0.87$ and $r_{\mathrm{s}}=-0.204 ; P=0.33$, respectively). 
Pod production was significantly higher in $\mathrm{M}$ plots than in $\mathrm{Sw}$ and NoA plots, the effect of $\mathrm{Ch}$ amendment being intermediate (Fig. 1). Earthworm inoculation exerted no significant effect on pod production (Table 3). However, there was an inversion of the earthworm effect between manioc peels and the other amendments (Fig. 1). Pod production seemed to be negatively influenced by earthworm addition in NoA, Sw and Ch plots, but positively influenced in M plots. We compared Ew and NoEw plots for the same amendment by a Mann-Whitney test. For each amendment, there was no significant effect of earthworm inoculation on pod production at the density chosen (80 subadults $\mathrm{m}^{-2}$ ).

The effects of amendment and earthworm inoculation on plant survival and density of $P$. corethrurus were not significant (Table 3).

Effects of amendments and earthworm treatments on soil chemical properties

Chemical soil properties under the different treatments in NoL and L plots are given in Table 4 and Table 5, respectively. Soil acidity was significantly lower (higher $\mathrm{pH}$ ) in plots amended with $\mathrm{Ch}$ as compared to the other treatments. Total soil C was significantly higher in Sw plots as compared to NoA and M plots, and intermediate in Ch plots. Available $\mathrm{P}$ and the ratio $\mathrm{P}_{\mathrm{av}}: \mathrm{P}_{\text {tot }}$ were higher in $\mathrm{M}$ than in other amendments. There was no significant effect of amendment on total $\mathrm{N}$, total $\mathrm{K}$, exchangeable $\mathrm{K}$ extracted at $\mathrm{pH} 7\left(\mathrm{~K}_{\mathrm{ac}}\right)$, difference and ratio to $\mathrm{K}_{\text {tot }}$ and exchangeable potassium extracted at soil $\mathrm{pH}\left(\mathrm{K}_{\mathrm{co}}\right)$, except for the ratio $\mathrm{K}_{\mathrm{co}}: \mathrm{K}_{\mathrm{tot}}$ in $\mathrm{L}$ plots (Tables 3 and 5). The ratio $K_{\mathrm{co}}: \mathrm{K}_{\mathrm{tot}}$ was significantly higher with $\mathrm{M}$ amendment than in NoA soil in $\mathrm{L}$ plots, the ratio being intermediate in $\mathrm{Sw}$ and $\mathrm{Ch}$ plots. The $\mathrm{C}: \mathrm{N}$ ratio was significantly affected by treatments, but no group could be isolated by multiple comparisons (Tukey test). Nevertheless, plots amended with Sw and Ch had higher C:N ratios than plots amended with $\mathrm{M}$ or not amended.

Earthworm inoculation did not exert any significant effect on soil acidity and nutrient content in NoL and $\mathrm{L}$ plots (Table 3), but there was an interaction between amendment and earthworm inoculation for total $\mathrm{C}$ and $\mathrm{P}_{\mathrm{av}}: \mathrm{P}_{\text {tot }}$ ratio (Table 3). Total $\mathrm{C}$ was significantly higher in $\mathrm{Ch} / \mathrm{NoL}$ plots with earthworm inoculation than without (Table 4), whereas there was no earthworm effect with the other amendments. The ratio $\mathrm{P}_{\mathrm{av}}: \mathrm{P}_{\text {tot }}$ was significantly higher in M/L plots with earthworm inoculation than without (Table 5), whereas the opposite effect of earthworm inoculation occurred in no-amendment plots, no earthworm effect being observed for $\mathrm{Sw}$ and $\mathrm{Ch}$ amendments. 
Interactions between soil, plants and earthworms

The number of yard-long bean shoots per plot was not significantly correlated with earthworm density nor with soil chemical data.

Earthworm density was positively correlated with pod production $\left(r_{\mathrm{s}}=0.546 ; P=0.006\right)$ and with plant survival $\left(r_{\mathrm{s}}=0.438 ; P=0.032\right)$. Table 6 shows a high number of significant correlation coefficients between soil moisture and nutrients and pod production or earthworm density and fewer with plant survival. There was a significant negative correlation between the moisture index and plant survival, pod production, earthworm density, soil acidity and nutrient content, except for $\mathrm{P}_{\mathrm{av}}: \mathrm{P}_{\text {tot }}$ (Table 6). There was no significant correlation between the moisture index and the number of mature plants per plot.

\section{Discussion}

The legume V. unguiculata sesquipedalis (Fabaceae) was affected by controlled and non-controlled factors in this bioassay. Indeed we can attribute to water-logging, which causes oxygen depletion (Brady and Weil 1999), the general low pod production (the highest mean fresh weight of pods produced by a plant did not exceed 30.5 g) and the high variability of plant survival $(45 \pm 7 \%$, mean \pm SE). The success of plant maturation represented by the number of mature plants per plot was not affected by soil moisture, probably because soil water-logging following the high rainfall of January and February appeared after plants became adult. Amendments influenced pod production too, manioc peels showing a beneficial effect (compared to not-amended soil and sawdust, charcoal being intermediate). Manioc peels have a higher $\mathrm{P}$ and $\mathrm{K}$ content and a lower $\mathrm{C}: \mathrm{N}$ ratio than wood charcoal and sawdust (Table 2), improving the soil in available $\mathrm{P}$ and increasing the availability of exchangeable $\mathrm{K}$ in the presence of $V$. unguiculata. M. esculenta is known to be a very toxic plant with a high content of cyanide, $344.2 \mathrm{mg} \mathrm{kg}^{-1}$ in air-dried peels (Mba 1983). In the study by Mba (1983), the earthworm Eudrilus Eugenia transformed the manioc peels to a nutrient-rich vermicompost with a low content of cyanide. In our experiment, no negative effects of manioc peels were revealed either on legume survival or on earthworm density. This indicates that manioc peels were not toxic for V. unguiculata and P. corethrurus. Wood charcoal, which strongly decreased soil acidity and provided $\mathrm{C}$, improved pod production but to a lesser extent than manioc peels. Sawdust did not improve pod production, probably due to its low nutrient content (Senapati et al. 
1999). All these results suggested that pod production of $V$. unguiculata was very sensitive to available $P$, plant survival being linked with exchangeable $\mathrm{K}$. The success of plant maturation, which was not affected by earthworm inoculation and amendment, probably depended on intrinsic parameters.

Pod production and earthworm density were positively correlated with soil $\mathrm{N}$ content. We did not observe any enrichment of the soil in $\mathrm{N}$ under the influence of the legume. It is possible that nitrogen-fixing symbiotic bacteria specific to $V$. unguiculata were not present in our soil or that environmental conditions such as high acidity were not suitable for their activity (Wolff et al. 1993). Thus we consider that pod production was enhanced in plots with a high soil $\mathrm{N}$ content through the positive effect of $P$. corethrurus on $\mathrm{N}$ mineralisation (Barois et al. 1987; González and Zou 1999).

Favourable effects of $P$. corethrurus on plant production depend on plant species and earthworm density (Pashanasi et al. 1992). At a density of 90 individuals $\mathrm{m}^{-2}$, the introduction of $P$. corethrurus showed a positive effect on maize grain production (Pashanasi et al. 1996). In this bioassay, the inoculation of $P$. corethrurus at a density of 80 sub-adults $\mathrm{m}^{-2}$ did not exert any significant effect on pod production. Yet, the inoculation of $P$. corethrurus reinforced the positive effect of manioc peel amendment on pod production and on P availability, the opposite effect being depicted by sawdust and wood charcoal. It seems that $P$. corethrurus enhanced the decomposition of manioc peels. This earthworm species, which is considered geophagous (Lavelle 1983), can also digest plant debris thanks to a quite complete enzymatic system produced in its gut (Lattaud et al. 1998; Zhang et al. 1993). This capability could permit the digestion of manioc peels, releasing nutrients and more especially P in a plant-available form (Lopez-Hernandez et al. 1993; Patron et al. 1999).

At a very high density (400 individuals $\mathrm{m}^{-2}$ ), it has been shown that $P$. corethrurus could cause severe compaction of soil in pastures, this phenomenon being reinforced by heavy machinery and cattle trampling (Chauvel et al. 1999). Another study demonstrated that $P$. corethrurus compacted the soil in a biofertilisation assay only when it was inoculated without amendment (Hallaire et al. 2000). At the density inoculated in the present study (80 individuals $\left.\mathrm{m}^{-2}\right), P$. corethrurus may not have any negative effect on soil structure, the highest density found in plots being 160 individuals $\mathrm{m}^{-2}$.

Four months after the start of our experiment, the total density of $P$. corethrurus in plots was not influenced by amendments nor by initial inoculation. The mean density of this species $\left(29.3\right.$ ind. $\mathrm{m}^{-2} \pm 9.8$, mean $\pm \mathrm{SE}$ ) in the rainy season was lower than the density of the natural population found under vegetation cover in the dry season (37.3 ind. $\mathrm{m}^{-2} \pm 7.3$, mean $\pm \mathrm{SE}$ ). Nevertheless the highest density of $P$. corethrurus was found in 
plots where pod production and plant survival were the highest too, those plots having the lowest soil moisture according to visual assessment. Our results suggest that the experimental system undelimited in depth allowed earthworms to retreat from water-logged plots. P. corethrurus exhibits a high range of tolerance to several environmental factors such as soil acidity and can tolerate dryness but it is negatively affected by too much soil moisture (Lavelle et al. 1987). This species exhibits an aggregative distribution conditioned by food availability and abiotic conditions (Barois et al. 1999). We may suppose that inoculated earthworms died or moved to plots with better living conditions before the start of pod production, so pod production could be enhanced after the redistribution of earthworms coming from inoculated and natural populations.

We conclude that, in this bioassay, the indirect interaction between P. corethrurus and V. unguiculata was mediated by soil nutrient content and soil moisture (Brown et al. 1999). We did not prove that the inoculated population of $P$. corethrurus exerted a stronger effect on pod production than the natural one, except through improvement of $\mathrm{P}$ availability in manioc-amended plots. New bioassays with mixtures of amendments, especially manioc peels mixed with wood charcoal, will provide complementary results about the efficiency of organic manure for the long-lasting production of yard-long bean.

Acknowledgements The study was supported by the "Mission pour la Création du Parc du Sud de la Guyane" for the realisation of the field bioassay. We wish to thank Mr Lobbini and his son for technical assistance in the field.

\section{References}

AFNOR (1996) Qualité des sols. Recueil de normes françaises, 3rd edn. La Défense, Paris

Anderson JM, Ingram J (1993) Tropical soil biology and fertility. A handbook of methods, 2nd edn. CAB, Oxford

Barois I, Verdier B, Kaiser P, Mariotti A, Rangel P, Lavelle P (1987) Influence of the tropical earthworm Pontoscolex corethrurus (Glossoscolecidae) on the fixation and mineralization of nitrogen. In: Bonvicini Pagliai AM, Omodeo P (eds) On earthworms, vol 2. (Selected symposia and monographs) Mucchi, Modena, pp 151-158 
Barois I, Lavelle P, Brossard M, Tondoh J, Martinez M, Rossi J, Senapati B, Angeles A, Fragoso C, Jimenez J, Decaens T, Lattaud C, Kanyonyo J, Blanchart E, Chapuis L, Brown G, Moreno A (1999) Ecology of earthworm species with large environmental tolerance and/or extended distributions. In: Lavelle P, Brussaard L, Hendrix P (eds) Earthworm management in tropical agroecosystems. CAB International, London, pp 57-85

Brady NC, Weil RR (1999) The nature and properties of soils, 12th edn. Prentice-Hall, New Jersey

Brown GG, Pashanasi B, Villenave C, Patron JC, Senapati BK, Giri S, Barois I, Lavelle P, Blanchart E, Blackemore RI, Spain AV, Boyer J (1999) Effects of earthworms on plant production in the tropics. In: Lavelle P, Brussaard L, Hendrix P (eds) Earthworm management in tropical agroecosystems. CAB International, London, pp 87-147

Chauvel A, Grimaldi M, Barros E, Blanchart E, Desjardins T, Sarrazin M, Lavelle P (1999) Pasture damage by an Amazonian earthworm. Nature 398:32-33

Clarke WC (1976) Maintenance of agriculture and human habitats within the tropical forest ecosystem. Hum Ecol 4:247-259

González G, Zou X (1999) Earthworm influence on N availability and the growth of Cecropia schreberiana in tropical pasture and forest soils. Pedobiologia 43:824-829

Hallaire V, Curmi P, Duboisset A, Lavelle P, Pashanasi B (2000) Soil structure changes induced by the tropical earthworm Pontoscolex corethrurus and organic inputs in a Peruvian ultisol. Eur J Soil Biol 36:35-44

Lattaud C, Locati S, Mora P, Rouland C, Lavelle P (1998) The diversity of digestive systems in tropical geophagous earthworms. Appl Soil Ecol 9:189-195

Lavelle P (1983) The structure of earthworm communities. In: Satchell JE (eds) Earthworm ecology, from Darwin to vermiculture. Chapman and Hall, London, pp 449-465

Lavelle P, Barois I, Cruz I, Fragoso C, Hernandez A, Pineda A, Rangel P (1987) Adaptive strategies of Pontoscolex corethrurus (Glossoscolecidae, Oligochaeta), a peregrine geophagous earthworm of the humid tropics. Biol Fertil Soils 5:188-194 
Lavelle P, Barros E, Blanchart E, Brown G, Desjardins T, Mariani L (2001) SOM management in the tropics: why feeding the soil macrofauna? Nutr Cycl Agroecosyst 61:53-61

Lopez-Hernandez D, Lavelle P, Fardeau JC, Niño M (1993) Phosphorus transformations in two P-sorption contrasting tropical soils during transit through Pontoscolex corethrurus (Glossoscolecidae: Oligochaeta). Soil Biol Biochem 25:789-792

Mba CC (1983) Utilization of Eudrilus eugeniae for disposal of cassava peel. In: Satchell JE (eds) Earthworm ecology, from Darwin to vermiculture. Chapman and Hall, London, pp 315-321

Palm CA, Giller KE, Mafongoya PL, Swift MJ (2001) Management of organic matter in the tropics: translating theory into practice. Nutr Cycl Agroecosyst 61:63-75

Pashanasi B, Melendez G, Szott L, Lavelle P (1992) Effect of inoculation with the endogeic earthworm Pontoscolex corethrurus (Glossoscolecidae) on N availability, soil microbial biomass and the growth of three tropical fruit tree seedlings in a pot experiment. Soil Biol Biochem 24:1655-1659

Pashanasi B, Lavelle P, Alegre J, Charpentier F (1996) Effect of the endogeic earthworm Pontoscolex corethrurus on soil chemical characteristics and plant growth in a low-input tropical agroecosystem. Soil Biol Biochem 28:801-810

Patron JC, Sanchez P, Brown GG, Brossard M, Barois I, Gutierrez C (1999) Phosphorus in soil and Brachiaria decumbens plants as affected by the geophagous earthworm Pontoscolex corethrurus and P fertilization. Pedobiologia 43:547-556

Righi G (1984) Pontoscolex (Oligochaeta, Glossoscolecidae) a new evaluation. Stud Neotrop Fauna Environ 19:159-177

Senapati BK, Lavelle P, Giri S, Pashanasi B, Alegre J, Decaëns T, Jimenez JJ, Albrecht A, Blanchart E, Mahieux M, Rousseaux L, Thomas R, Panigrahi PK, Venkatachalam M (1999) In-soil earthworm technologies for tropical agroecosystems. In: Lavelle P, Brussaard L, Hendrix P (eds) Earthworm management in tropical agroecosystems. CAB International, London, pp 199-237

Sokal RR, Rohlf FI (1995) Biometry, 3rd edn. Freeman, New York 
Tiessen H, Sampaio EVSB, Salcedo IH (2001) Organic matter turnover and management in low input agriculture of NE Brazil. Nutr Cycl Agroecosyst 61:99-103

Wolff AB, Singleton PW, Sidirelli M, Bohllol BB (1993) Influence of acid soil on nodulation and interstrain competitiveness in relation to tannin concentrations in seeds and roots of Phaseolus vulgaris. Soil Biol Biochem 25:715-721

Zhang BG, Rouland C, Lattaud C, Lavelle P (1993) Activity and origin of digestive enzymes in gut of the tropical earthworm Pontoscolex corethrurus. Eur J Soil Biol 29:7-11 


\section{Legends of figures}

Fig. 1 Yard-long bean production (mean fresh weight per shoot) according to amendment and earthworm treatment. Bars represent standard error. Treatments are abbreviated as following: manioc $(M)$, wood charcoal $(C h)$, sawdust $(S w)$, unamended soil $(N o A)$, inoculation of earthworms $(E w)$, no inoculation of earthworms $(N o E w)$, presence of legumes $(L)$ and no presence of legumes $(N o L)$ 
Table 1 Soil chemical composition of the upper $15 \mathrm{~cm}$ of the soil. Measurement of $\mathrm{pH}$ was done in water with a soil:water ratio of $1: 2.5(\mathrm{w} / \mathrm{w})$

\begin{tabular}{lll}
\hline & & Mean $\pm \mathrm{SE}$ \\
\hline $\mathrm{pH}$ & $(\mathrm{H} 2 \mathrm{O})$ & $5.25 \pm 0.16$ \\
Total C & $\left(\mathrm{g} \mathrm{kg}^{-1}\right)$ & $28.8 \pm 4.4$ \\
Total $\mathrm{N}$ & $\left(\mathrm{g} \mathrm{kg}^{-1}\right)$ & $1.85 \pm 0.20$ \\
$\mathrm{C}: \mathrm{N}$ ratio & & $15.3 \pm 0.8$ \\
Available $\mathrm{P}\left(\mathrm{P}_{\mathrm{av}}\right)$ & $\left(\mathrm{mg} \mathrm{kg}^{-1}\right)$ & $21.50 \pm 2.40$ \\
Exchangeable $\mathrm{K}_{\mathrm{ac}}{ }^{\mathrm{a}}$ & $\left(\mathrm{mg} \mathrm{kg}^{-1}\right)$ & $10.5 \pm 2.2$ \\
Exchangeable $\mathrm{K}_{\mathrm{co}} \mathrm{b}$ & $\left(\mathrm{mg} \mathrm{kg}^{-1}\right)$ & $8.48 \pm 2.2$ \\
Total $\mathrm{P}\left(\mathrm{P}_{\text {tot }}\right)$ & $\left(\mathrm{mg} \mathrm{kg}^{-1}\right)$ & $4.20 \pm 0.46$ \\
Total K $\left(\mathrm{K}_{\text {tot }}\right)$ & $\left(\mathrm{mg} \mathrm{kg}^{-1}\right)$ & $10.3 \pm 0.8$ \\
$\mathrm{~K}_{\mathrm{ac}}: \mathrm{K}_{\text {tot }}$ & $\%$ & $1.01 \pm 0.17$ \\
$\mathrm{~K}_{\mathrm{co}}: \mathrm{K}_{\text {tot }}$ & $\%$ & $0.807 \pm 0.173$ \\
$\mathrm{P}_{\mathrm{av}}: \mathrm{P}_{\text {tot }}$ & $\%$ & $4.91 \pm 0.44$ \\
\hline
\end{tabular}

${ }^{\mathrm{a}}$ Exchangeable $\mathrm{K}$ with ammonium acetate

${ }^{\mathrm{b}}$ Exchangeable $\mathrm{K}$ with hexamine cobalt 
Table 2 Chemical composition of the different amendments. Measurement of $\mathrm{pH}$ was done in water with a substrate:water ratio of $1: 2.5(\mathrm{w} / \mathrm{w})$

\begin{tabular}{lllll}
\hline & & Manioc peels & Wood charcoal & Sawdust \\
\hline pH & $(\mathrm{H} 2 \mathrm{O})$ & 6.72 & 9.60 & 5.31 \\
Ashes & $(\%)$ & 31.9 & 3.80 & 2.35 \\
Total C & $\left(\mathrm{g} \mathrm{kg}^{-1}\right)$ & 356 & 905 & 521 \\
Total N & $\left(\mathrm{g} \mathrm{kg}^{-1}\right)$ & 24.2 & 5.64 & 5.13 \\
C:N ratio & $\left(\mathrm{g} \mathrm{kg}^{-1}\right)$ & 14.71 & 160 & 102 \\
Total P & $\left(\mathrm{g} \mathrm{kg}^{-1}\right)$ & 2.26 & 0.268 & 0.0633 \\
Total K & $\left(\mathrm{g} \mathrm{kg}^{-1}\right)$ & 10.3 & 5.05 & 0.347 \\
\hline
\end{tabular}


Table 3 Effects of amendment, earthworm inoculation and amendment $\times$ earthworm interaction on legume characteristics and soil nutrient contents. F and P values of ANOVA are given for each factor. For legume characteristics factors were tested on the 24 plots containing legume shoots. For soil nutrient contents factors were tested on the plots with legume shoots $(L$ plots $)$ and plots without $($ NoL plots $)$. Significant results $(P<0.05)$ are in bold

\begin{tabular}{|c|c|c|c|c|c|c|}
\hline & \multicolumn{2}{|c|}{ Amendment (1) } & \multicolumn{2}{|c|}{ Earthworm inoculation (2) } & \multicolumn{2}{|c|}{ Interaction $(1) \times(2)$} \\
\hline & $\mathrm{F}$ & $\mathrm{P}$ & $\mathrm{F}$ & $\mathrm{P}$ & $\mathrm{F}$ & $\mathrm{P}$ \\
\hline Mature shoots number & 0.369 & 0.776 & 3.938 & 0.065 & 0.123 & 0.945 \\
\hline Pod production & 7.842 & 0.002 & 0.472 & 0.502 & 1.19 & 0.345 \\
\hline Plant survival & 2.268 & 0.12 & 0.0595 & 0.81 & 0.455 & 0.718 \\
\hline \multicolumn{7}{|l|}{ L plots } \\
\hline $\mathrm{pH}$ & 15.589 & $<0.001$ & 1.09 & 0.312 & 0.392 & 0.761 \\
\hline $\mathrm{C}$ & 7.446 & 0.002 & 3.047 & 0.1 & 2.418 & 0.104 \\
\hline $\mathrm{N}$ & 1.906 & 0.169 & 2.541 & 0.13 & 1.898 & 0.171 \\
\hline $\mathrm{P}_{\text {tot }}$ & 4.049 & 0.026 & 0.78 & 0.39 & 2.66 & 0.083 \\
\hline $\mathrm{P}_{\mathrm{av}}$ & 17.964 & $<0.001$ & 1.437 & 0.248 & 1.143 & 0.362 \\
\hline $\mathrm{P}_{\mathrm{tot}}-\mathrm{P}_{\mathrm{av}}$ & 3.255 & 0.049 & 0.688 & 0.419 & 3.049 & 0.059 \\
\hline $\mathrm{P}_{\mathrm{av}}: \mathrm{P}_{\mathrm{tot}}$ & 19.539 & $<0.001$ & 1.213 & 0.287 & 6.702 & 0.004 \\
\hline $\mathrm{K}_{\text {tot }}$ & 0.304 & 0.822 & 1.446 & 0.247 & 1.018 & 0.411 \\
\hline $\mathrm{K}_{\mathrm{ac}}$ & 1.727 & 0.202 & 1.139 & 0.302 & 1.081 & 0.85 \\
\hline $\mathrm{K}_{\mathrm{co}}$ & 1.586 & 0.232 & 0.384 & 0.544 & 0.24 & 0.867 \\
\hline $\mathrm{K}_{\mathrm{ac}}: \mathrm{K}_{\mathrm{tot}}$ & 2.401 & 0.106 & 0.702 & 0.415 & 2.064 & 0.145 \\
\hline $\mathrm{K}_{\mathrm{co}}: \mathrm{K}_{\mathrm{tot}}$ & 3.301 & 0.047 & 0.00655 & 0.936 & 0.462 & 0.713 \\
\hline \multicolumn{7}{|l|}{ NoL plots } \\
\hline $\mathrm{pH}$ & 13.588 & $<0.001$ & 0.0295 & 0.866 & 0.337 & 0.799 \\
\hline $\mathrm{C}$ & 3.99 & 0.063 & 10.967 & $<0.001$ & 4.123 & 0.024 \\
\hline $\mathrm{N}$ & 2.123 & 0.137 & 3.5 & 0.08 & 4.164 & 0.023 \\
\hline $\mathrm{P}_{\text {tot }}$ & 0.798 & 0.513 & 4.031 & 0.062 & 0.888 & 0.468 \\
\hline $\mathrm{P}_{\mathrm{av}}$ & 5.619 & 0.008 & 2.433 & 0.138 & 1.233 & 0.33 \\
\hline $\mathrm{P}_{\mathrm{tot}}-\mathrm{P}_{\mathrm{av}}$ & 1.031 & 0.405 & 3.676 & 0.073 & 0.85 & 0.487 \\
\hline $\mathrm{P}_{\mathrm{av}}: \mathrm{P}_{\text {tot }}$ & 8.549 & 0.001 & 0.0979 & 0.758 & 0.998 & 0.419 \\
\hline $\mathrm{K}_{\mathrm{tot}}$ & 3.238 & 0.05 & 4.159 & 0.058 & 1.58 & 0.233 \\
\hline $\mathrm{K}_{\mathrm{ac}}$ & 2.09 & 0.142 & 3.238 & 0.091 & 1.047 & 0.399 \\
\hline $\mathrm{K}_{\mathrm{co}}$ & 2.562 & 0.091 & 2.298 & 0.149 & 0.778 & 0.523 \\
\hline $\mathrm{K}_{\mathrm{ac}}: \mathrm{K}_{\mathrm{tot}}$ & 1.976 & 0.158 & 0.865 & 0.366 & 0.242 & 0.866 \\
\hline $\mathrm{K}_{\mathrm{co}}: \mathrm{K}_{\mathrm{tot}}$ & 2.616 & 0.087 & 0.265 & 0.614 & 0.0904 & 0.964 \\
\hline
\end{tabular}


Table 4 Nutrient content of the soil according to treatments in plots without legumes (NoL; means of three blocks $\pm \mathrm{SE})$. Treatments are abbreviated as following: manioc $(M)$, wood charcoal $(C h)$, sawdust $(S w)$, unamended soil $(N o A)$, inoculation of earthworms $(E w)$ and no inoculation of earthworms (NoEw). Significant differences among means are denoted by different letters $(P<0.05)$

\begin{tabular}{|c|c|c|c|c|c|c|c|c|c|}
\hline & & \multicolumn{4}{|l|}{ NoEw } & \multicolumn{4}{|l|}{ Ew } \\
\hline $\mathrm{pH}$ & $\mathrm{H}_{2} \mathrm{O}$ & $5.12 \pm 0.16 \mathrm{~b}$ & $5.33 \pm 0.11 \mathrm{~b}$ & $5.92 \pm 0.11 \mathrm{a}$ & $5.12 \pm 0.16 \mathrm{~b}$ & $5.15 \pm 0.10 \mathrm{~b}$ & $5.41 \pm 0.11 \mathrm{~b}$ & $5.76 \pm 0.19 \mathrm{a}$ & $5.10 \pm 0.06 \mathrm{~b}$ \\
\hline $\mathrm{N}$ & $\mathrm{g} \mathrm{kg}^{-1}$ & $1.61 \pm 0.22 \mathrm{a}$ & $1.21 \pm 0.08 \mathrm{ab}$ & $0.973 \pm 0.056 b$ & $1.25 \pm 0.07 \mathrm{ab}$ & $1.46 \pm 0.22 \mathrm{ab}$ & $1.10 \pm 0.13 b$ & $1.75 \pm 0.18 \mathrm{a}$ & $1.53 \pm 0.14 \mathrm{ab}$ \\
\hline $\mathrm{C} / \mathrm{N}$ & & $14.3 \pm 0.3 \mathrm{a}$ & $13.7 \pm 0.3 \mathrm{a}$ & $21.1 \pm 1.1 \mathrm{a}$ & $21.9 \pm 3.1 \mathrm{a}$ & $13.7 \pm 0.4 \mathrm{a}$ & $13.5 \pm 0.5 \mathrm{a}$ & $20.2 \pm 3.2 \mathrm{a}$ & $21.9 \pm 1.0 \mathrm{a}$ \\
\hline $\mathrm{P}_{\mathrm{tot}}$ & $\mathrm{mg} \mathrm{kg}^{-1}$ & $273 \pm 22 \mathrm{a}$ & $217 \pm 35 a$ & $193 \pm 20 \mathrm{a}$ & $213 \pm 27 \mathrm{a}$ & $287 \pm 67 a$ & $243 \pm 18 \mathrm{a}$ & $313 \pm 34 a$ & $257 \pm 38 \mathrm{a}$ \\
\hline $\mathrm{K}_{\mathrm{tot}}$ & $\mathrm{mg} \mathrm{kg}^{-1}$ & $700 \pm 57 a$ & $500 \pm 58 \mathrm{a}$ & $533 \pm 33 a$ & $533 \pm 67 \mathrm{a}$ & $700 \pm 115 \mathrm{a}$ & $567 \pm 33 a$ & $800 \pm 58 \mathrm{a}$ & $567 \pm 33 a$ \\
\hline $\mathrm{K}_{\mathrm{ac}}$ & $\mathrm{mg} \mathrm{kg}^{-1}$ & $26.8 \pm 3.9 \mathrm{a}$ & $25.0 \pm 7.0 \mathrm{a}$ & $28.1 \pm 5.5 \mathrm{a}$ & $20.9 \pm 1.0 \mathrm{a}$ & $29.3 \pm 9.4 \mathrm{a}$ & $27.6 \pm 4.9 \mathrm{a}$ & $51.2 \pm 11.9 \mathrm{a}$ & $27.3 \pm 4.5 \mathrm{a}$ \\
\hline $\mathrm{K}_{\mathrm{co}}$ & $\mathrm{mg} \mathrm{kg}^{-1}$ & $28.6 \pm 5.7 \mathrm{a}$ & $27.3 \pm 5.6 \mathrm{a}$ & $32.5 \pm 7.9 \mathrm{a}$ & $20.8 \pm 1.3 \mathrm{a}$ & $29.9 \pm 9.1 \mathrm{a}$ & $31.2 \pm 8.1 \mathrm{a}$ & $54.6 \pm 12.5 \mathrm{a}$ & $26.0 \pm 4.7 \mathrm{a}$ \\
\hline $\mathrm{K}_{\mathrm{tot}}-\mathrm{K}_{\mathrm{ac}}$ & $\mathrm{mg} \mathrm{kg}^{-1}$ & $673 \pm 55 a$ & $475 \pm 52 a$ & $505 \pm 28 \mathrm{a}$ & $512 \pm 66 \mathrm{a}$ & $671 \pm 106 a$ & $539 \pm 31 \mathrm{a}$ & $749 \pm 51 \mathrm{a}$ & $539 \pm 33 a$ \\
\hline $\mathrm{K}_{\mathrm{tot}}-\mathrm{K}_{\mathrm{co}}$ & $\mathrm{mg} \mathrm{kg}^{-1}$ & $671 \pm 22 \mathrm{a}$ & $473 \pm 53 a$ & $501 \pm 26 a$ & $512 \pm 66 \mathrm{a}$ & $670 \pm 106 a$ & $535 \pm 28 \mathrm{a}$ & $745 \pm 51 \mathrm{a}$ & $541 \pm 38 \mathrm{a}$ \\
\hline $\mathrm{K}_{\mathrm{ac}}: \mathrm{K}_{\mathrm{tot}}$ & $\%$ & $3.83 \pm 0.44 \mathrm{a}$ & $4.86 \pm 0.87 \mathrm{a}$ & $5.18 \pm 0.66 \mathrm{a}$ & $4.04 \pm 0.49 \mathrm{a}$ & $3.98 \pm 0.65 \mathrm{a}$ & $4.84 \pm 0.78 \mathrm{a}$ & $6.32 \pm 1.32 \mathrm{a}$ & $4.84 \pm 0.78 \mathrm{a}$ \\
\hline
\end{tabular}


Table 5 Nutrient content of the soil according to treatments in plots with legumes $(L$; means of three blocks \pm SE). Treatments are abbreviated as following: manioc $(M)$, wood charcoal $(C h)$, sawdust $(S w)$, unamended soil $(N o A)$, inoculation of earthworms $(E w)$ and no inoculation of earthworms $(N o E w)$. Significant differences among means are denoted by different letters $(P<0.05)$

\begin{tabular}{|c|c|c|c|c|c|c|c|c|c|}
\hline & & \multicolumn{4}{|l|}{ NoEw } & \multicolumn{4}{|l|}{ Ew } \\
\hline & & NoA & M & $\mathrm{Ch}$ & Sw & NoA & $\mathrm{M}$ & $\mathrm{Ch}$ & $\mathrm{Sw}$ \\
\hline $\mathrm{pH}$ & $\mathrm{H}_{2} \mathrm{O}$ & $4.99 \pm 0.03 b$ & $4.97 \pm 0.08 b$ & $5.59 \pm 0.13 a$ & $5.19 \pm 0.13 b$ & $5.13 \pm 0.07 b$ & $4.98 \pm 0.02 b$ & $5.79 \pm 0.22 \mathrm{a}$ & $5.18 \pm 0.11 b$ \\
\hline $\mathrm{C}$ & $\mathrm{g} \mathrm{kg}^{-1}$ & $22.4 \pm 2.6 b$ & $20.0 \pm 0.9 \mathrm{~b}$ & $27.2 \pm 5.0 \mathrm{ab}$ & $40.9 \pm 6.9 \mathrm{a}$ & $14.1 \pm 1.28 b$ & $22.2 \pm 2.1 \mathrm{~b}$ & $29.2 \pm 4.4 \mathrm{ab}$ & $26.8 \pm 1.2 \mathrm{a}$ \\
\hline $\mathrm{N}$ & $\mathrm{g} \mathrm{kg}^{-1}$ & $1.54 \pm 0.10 \mathrm{a}$ & $1.49 \pm 0.08 \mathrm{a}$ & $1.37 \pm 0.21 \mathrm{a}$ & $1.87 \pm 0.33 \mathrm{a}$ & $1.06 \pm 0.1 \mathrm{a}$ & $1.65 \pm 0.10 \mathrm{a}$ & $1.39 \pm 0.16 \mathrm{a}$ & $1.42 \pm 0.04 \mathrm{a}$ \\
\hline $\mathrm{C} / \mathrm{N}$ & & $14.5 \pm 0.8 \mathrm{a}$ & $13.4 \pm 0.1 \mathrm{a}$ & $19.9 \pm 2.8 \mathrm{a}$ & $21.9 \pm 0.3 \mathrm{a}$ & $13.3 \pm 0.1 \mathrm{a}$ & $13.4 \pm 0.5 \mathrm{a}$ & $21.1 \pm 2.4 \mathrm{a}$ & $18.8 \pm 0.6 \mathrm{a}$ \\
\hline $\mathrm{P}_{\text {tot }}$ & $\mathrm{mg} \mathrm{kg}^{-1}$ & $297 \pm 33 a b$ & $310 \pm 15 a$ & $210 \pm 38 b$ & $297 \pm 44 a b$ & $190 \pm 26 b$ & $347 \pm 27 a$ & $250 \pm 36 b$ & $250 \pm 12 b$ \\
\hline $\mathrm{P}_{\mathrm{av}}$ & $\mathrm{mg} \mathrm{kg}^{-1}$ & $10.7 \pm 2.3 b$ & $29.0 \pm 4.0 \mathrm{a}$ & $10.3 \pm 1.2 \mathrm{~b}$ & $11.3 \pm 1.5 b$ & $10.0 \pm 0.2 b$ & $21.7 \pm 4.4 \mathrm{a}$ & $11.7 \pm 0.7 b$ & $9.67 \pm 0.88 b$ \\
\hline $\mathrm{P}_{\mathrm{tot}}-\mathrm{P}_{\mathrm{av}}$ & $\mathrm{mg} \mathrm{kg}^{-1}$ & $286 \pm 31 \mathrm{ab}$ & $281 \pm 13 \mathrm{ab}$ & $200 \pm 37 b$ & $285 \pm 43 a b$ & $180 \pm 25 b$ & $325 \pm 23 a$ & $238 \pm 35 b$ & $240 \pm 11 \mathrm{ab}$ \\
\hline $\mathrm{P}_{\mathrm{av}}: \mathrm{P}_{\text {tot }}$ & $\%$ & $3.56 \pm 0.53 \mathrm{~d}$ & $9.31 \pm 1.00 \mathrm{a}$ & $5.05 \pm 0.67 \mathrm{~cd}$ & $3.84 \pm 0.79 \mathrm{~cd}$ & $5.26 \pm 0.37 \mathrm{c}$ & $6.15 \pm 0.81 b$ & $4.78 \pm 0.41 \mathrm{~cd}$ & $3.85 \pm 0.19 \mathrm{~cd}$ \\
\hline $\mathrm{K}_{\text {tot }}$ & $\mathrm{mg} \mathrm{kg}^{-1}$ & $767 \pm 120 \mathrm{a}$ & $667 \pm 67 a$ & $667 \pm 167 a$ & $667 \pm 88 a$ & $533 \pm 33 a$ & $733 \pm 33 a$ & $633 \pm 67 a$ & $567 \pm 33 a$ \\
\hline $\mathrm{K}_{\mathrm{ac}}$ & $\mathrm{mg} \mathrm{kg}^{-1}$ & $25.6 \pm 4.6 \mathrm{a}$ & $36.7 \pm 9.0 \mathrm{a}$ & $29.3 \pm 11.6 a$ & $36.0 \pm 2.6 \mathrm{a}$ & $17.4 \pm 3.1 \mathrm{a}$ & $38.5 \pm 10.8 \mathrm{a}$ & $33.2 \pm 5.4 \mathrm{a}$ & $16.0 \pm 6.6 \mathrm{a}$ \\
\hline $\mathrm{K}_{\mathrm{co}}$ & $\mathrm{mg} \mathrm{kg}^{-1}$ & $26.0 \pm 4.7 \mathrm{a}$ & $39.0 \pm 11.9 \mathrm{a}$ & $32.5 \pm 15.0 \mathrm{a}$ & $35.1 \pm 2.3 \mathrm{a}$ & $18.2 \pm 3.4 \mathrm{a}$ & $40.3 \pm 9.4 a$ & $33.8 \pm 5.7 \mathrm{a}$ & $26.0 \pm 2.6 \mathrm{a}$ \\
\hline $\mathrm{K}_{\mathrm{tot}}-\mathrm{K}_{\mathrm{ac}}$ & $\mathrm{mg} \mathrm{kg}^{-1}$ & $741 \pm 116 a$ & $630 \pm 58 \mathrm{a}$ & $637 \pm 155 a$ & $631 \pm 86 a$ & $516 \pm 31 a$ & $695 \pm 23 a$ & $600 \pm 62 a$ & $551 \pm 37 a$ \\
\hline $\mathrm{K}_{\mathrm{tot}}-\mathrm{K}_{\mathrm{co}}$ & $\mathrm{mg} \mathrm{kg}^{-1}$ & $741 \pm 115 a$ & $628 \pm 55 a$ & $634 \pm 152 a$ & $632 \pm 87 a$ & $515 \pm 31 a$ & $693 \pm 24 a$ & $599 \pm 61 \mathrm{a}$ & $541 \pm 32 \mathrm{a}$ \\
\hline $\mathrm{K}_{\mathrm{ac}}: \mathrm{K}_{\mathrm{tot}}$ & $\%$ & $3.33 \pm 0.19 \mathrm{a}$ & $5.35 \pm 0.76 a$ & $4.11 \pm 0.61 \mathrm{a}$ & $5.49 \pm 0.37 \mathrm{a}$ & $3.23 \pm 0.45 \mathrm{a}$ & $5.14 \pm 1.20 \mathrm{a}$ & $5.20 \pm 0.49 \mathrm{a}$ & $2.93 \pm 1.25 \mathrm{a}$ \\
\hline $\mathrm{K}_{\mathrm{co}}: \mathrm{K}_{\mathrm{tot}}$ & $\%$ & $3.37 \pm 0.07 b$ & $5.63 \pm 1.15 \mathrm{a}$ & $4.42 \pm 0.94 \mathrm{ab}$ & $5.40 \pm 0.54 \mathrm{ab}$ & $3.38 \pm 0.52 b$ & $5.41 \pm 1.00 \mathrm{ab}$ & $5.27 \pm 0.44 \mathrm{ab}$ & $4.59 \pm 0.37 \mathrm{ab}$ \\
\hline
\end{tabular}


Table 6 Correlations between soil moisture and soil chemical properties with pod production, earthworm density and plant survival ( $r_{\mathrm{s}}$ Spearman rank coefficient, $P$ probability, $N S$ no significant correlation).

\begin{tabular}{|c|c|c|c|c|}
\hline & Soil moisture ${ }^{b}$ & Pods production ${ }^{\mathrm{a}}$ & Earthworm density $^{\mathrm{b}}$ & Plant survival $^{\mathrm{a}}$ \\
\hline Soil moisture & & $r_{\mathrm{s}}=-0.623 ; P=0.001$ & $r_{\mathrm{s}}=-0.485 ; P=0.000$ & $r_{\mathrm{s}}=-0.686 ; P=0.000$ \\
\hline $\mathrm{pH}$ & $r_{\mathrm{s}}=-0.349 ; P=0.015$ & NS & NS & NS \\
\hline $\mathrm{C}$ & $r_{\mathrm{s}}=-0.368 ; P=0.010$ & NS & NS & NS \\
\hline $\mathrm{N}$ & $r_{\mathrm{s}}=-0.404 ; P=0.005$ & $r_{\mathrm{s}}=0.509 ; P=0.011$ & $r_{\mathrm{s}}=0.300 ; P=0.038$ & NS \\
\hline $\mathrm{C}: \mathrm{N}$ & NS & NS & NS & NS \\
\hline $\mathrm{P}_{\text {tot }}$ & $r_{\mathrm{s}}=-0.322 ; P=0.026$ & NS & NS & NS \\
\hline $\mathrm{P}_{\mathrm{av}}$ & $r_{\mathrm{s}}=-0.323 ; P=0.025$ & $r_{\mathrm{s}}=0.615 ; P=0.001$ & $r_{\mathrm{s}}=0.414 ; P=0.004$ & NS \\
\hline $\mathrm{P}_{\mathrm{tot}}-\mathrm{P}_{\mathrm{av}}$ & $r_{\mathrm{s}}=-0.285 ; P=0.049$ & NS & NS & NS \\
\hline $\mathrm{P}_{\mathrm{av}}: \mathrm{P}_{\text {tot }}$ & NS & $r_{\mathrm{s}}=0.480 ; P=0.018$ & $r_{\mathrm{s}}=0.338 ; P=0.019$ & NS \\
\hline $\mathrm{K}_{\mathrm{tot}}$ & $r_{\mathrm{s}}=-0.505 ; P=0.000$ & $r_{\mathrm{s}}=0.536 ; P=0.007$ & $r_{\mathrm{s}}=0.445 ; P=0.002$ & NS \\
\hline $\mathrm{K}_{\mathrm{co}}$ & $r_{\mathrm{s}}=-0.648 ; P=0.000$ & $r_{\mathrm{s}}=0.690 ; P=0.000$ & $r_{\mathrm{s}}=0.538 ; P=0.000$ & $r_{\mathrm{s}}=0.567 ; P=0.004$ \\
\hline $\mathrm{K}_{\mathrm{ac}}$ & $r_{\mathrm{s}}=-0.576 ; P=0.000$ & $r_{\mathrm{s}}=0.612 ; P=0.001$ & $r_{\mathrm{s}}=0.449 ; P=0.001$ & NS \\
\hline $\mathrm{K}_{\mathrm{tot}}-\mathrm{K}_{\mathrm{ac}}$ & $r_{\mathrm{s}}=-0.419 ; P=0.003$ & $r_{\mathrm{s}}=0.432 ; P=0.035$ & $r_{\mathrm{s}}=0.392 ; P=0.006$ & NS \\
\hline $\mathrm{K}_{\mathrm{tot}}-\mathrm{K}_{\mathrm{co}}$ & $r_{\mathrm{s}}=-0.397 ; P=0.005$ & $r_{\mathrm{s}}=0.436 ; P=0.033$ & $r_{\mathrm{s}}=0.370 ; P=0.010$ & NS \\
\hline $\mathrm{K}_{\mathrm{ac}}: \mathrm{K}_{\mathrm{tot}}$ & $r_{\mathrm{s}}=-0.373 ; P=0.009$ & $r_{\mathrm{s}}=0.516 ; P=0.010$ & NS & NS \\
\hline $\mathrm{K}_{\mathrm{co}}: \mathrm{K}_{\mathrm{tot}}$ & $r_{\mathrm{s}}=-0.471 ; P=0.000$ & $r_{\mathrm{s}}=0.646 ; P=0.000$ & $r_{\mathrm{s}}=0.396 ; P=0.006$ & $r_{\mathrm{s}}=0.584 ; P=0.003$ \\
\hline
\end{tabular}

${ }^{\mathrm{a}}$ Correlation measured on the $24 \mathrm{~L}$ plots

${ }^{\mathrm{b}}$ Correlation measured on the total 48 plots 
Fresh weight of pods per shoot (g)



Fig. 1 